\title{
Dynamics of Social Class Contempt in Contemporary British Television Comedy
}

\author{
Sharon Lockyer \\ School of Social Sciences \\ Brunel University \\ Uxbridge \\ Middlesex \\ UB8 3PH, UK \\ Tel: $+44(0) 1895267373$ \\ Email: Sharon.Lockyer@brunel.ac.uk
}




\title{
Dynamics of Social Class Contempt in \\ Contemporary British Television Comedy
}

\begin{abstract}
British television comedy has often ridiculed the complexities and characteristics of social class structures and identities. In recent years poor white socially marginalised groups, now popularly referred to as "chavs", have become a prevalent comedy target. One of the most popular and controversial television "comedy chavs" is Little Britain's fictional teenage single mother, Vicky Pollard. This paper examines the representation of Vicky Pollard in light of contemporary widespread abuse of the white working class. Highlighting the polysemic and ambivalent nature of Vicky Pollard's representation, the paper argues that whilst Little Britain's characterisation of Vicky Pollard largely contributes to contemporary widespread demonization of the working class, there are moments within Little Britain when a more sympathetic tone towards the poor working class may be read, and where chav identities are used to ridicule the pretensions, superficiality, and falsity of middle-class identities. The paper concludes that television comedy has been, and continues to be, a significant vehicle through which serious concerns, anxieties, and questions about social class and class identities are discursively constructed and contested.
\end{abstract}

Keywords: chavs; social class; television comedy; Little Britain; Vicky Pollard; interpretive diversity; representation 


\section{Introduction}

Sending up the dynamics and intricacies of the British class system has been a central ingredient of British television comedy since the 1950s. From Club Night (BBC 1957) through to The Royle Family (BBC 1998-2000, 2006, 2008) class struggles, differences, and tensions have been a source of comedy on the small screen.' Recently Andy Medhurst has argued that the "history of sitcom here has been preoccupied, to the point of obsession, with class" (2007, 145). However, whilst there is a wealth of critical analyses of the comedic representations of other locations of identity, such as gender (Andrews 1998; Chambers 2005; Gray 1994; Henry 2004; Hole 2003; Kirkham and Skeggs 1998; Porter 1998), sexuality (Battles and HiltonMorrow 2002; Gray 1998; Meyer 1994; Simpson 1998; Zizek 2000), and race and ethnicity (Howells 2006; Husband 1988; Medhurst 1998; Malik 2002; Pickering 1994), a comparatively small number of detailed critical analyses of British class comedy exist (Crowther and Pinfold 1987; Medhurst 2007; Wagg 1998). Mills argues that this neglect is partially explained by the lack of "visible groups fighting for the better depiction of social classes" $(2005,148)$.

This paper redresses this imbalance through a close analysis of class representations in a popular and controversial British television comedy sketch show - Little Britain (BBC 2003-present). Particular attention is given to how this sketch show represents a specific socially marginalised group popularly known as "chavs". The paper explores the comic treatment of "the chav" through qualitative textual analysis of chav teenage single mother Vicky Pollard. The paper focuses on Vicky Pollard's physical characteristics, her use of language, her character "defects", and the narratives in which she is embedded in order to explore how the representation reproduces, or challenges, stereotypical portrayals of socially marginalised identities, and to what extent Little Britain reproduces conventional comedic class discourses. 


\section{Class comedy in context}

A number of inter-related and overlapping themes dominate British comedic televisual representations of class. Medhurst $(2007,145)$ usefully identifies five main discursive themes that underpin class comedies. These include: comedies based on clashes between members of different classes who are portrayed as having little, if anything, in common (e.g. Keeping Up Appearances, BBC 1990-1995); comedies focussing on the difficulties of upward class mobility (e.g. Hancock's Half Hour, BBC 1956-1960); comedies serving to reinforce the central social position of middle classes (e.g. My Family, BBC 2000-present); comedies undermining and critiquing the social position of middle classes (e.g. Ever Decreasing Circles, BBC 1984-1989); and others seeking to ridicule the experiences, lifestyle and behaviours of specific social classes (e.g. Wayne and Waynetta Slob in Harry Enfield and Chums, BBC 1994-1997; Absolutely Fabulous, BBC 1992-1996, 2001-2005).ii

In one of the few analyses of British television comedic representations of social class Stephen Wagg argues that across 50 years of British television comedy, successful sitcoms have often "hinged on ideas of authenticity and pretension in class identities: one central character may be pompous/aspiring/convinced $s /$ he is better than all this, only to be trumped, time and again, by a doggedly unreconstructed companion" (1998, 2; see also Bowes 1990). For example, in Steptoe and Son (BBC 1962-1965, 1970-1974) rag and bone man Harold Steptoe's repeated attempts to climb the social class ladder are persistently surpassed by his contented and unpretentious father, Albert Steptoe. Wagg (1998) also identifies four other trends underpinning comedic British television portrayals of social class. Firstly, there is a dominance of middle class and upper class representations and fewer working class portrayals, resulting in a failure to acknowledge the existence of the working classes. This trend is also reflected in American television comedy 
(Butsch and Glennon 1983; Crowther and Pinfold 1987; Butsch 2003). As Mills notes, the implication of this pattern in social class portrayals is that it:

"reinforces power structures in which not only are such people denied access to the medium, but that the content of their lives is not deemed worthy of broadcast through it ... [and that] this is a result of the demographics of the television industry whose staff are overwhelmingly middle class" $(2005,149)$.

In addition to avoidance of working class representations three other trends identified by Wagg include a favouring towards "the tipster, the travelling salesman, the wheeler-and-dealer" character; an affection for "an aristocratic stereotype: effete, bumbling and possessed of extremely cumbersome names"; and finally, an interest in middle/upper class "media and showbusiness professions" (Wagg 1998, 4-5). These trends can be seen in Only Fools and Horses (BBC 1981-2003), To the Manor Born (BBC, 1979-1981, 2007), and Drop the Dead Donkey (Channel 4, 1990-1998) respectively.iii

These comedic class representations are important given television comedy's significant socio-political role. Comedy character types and characteristics need to be easily recognisable and understandable to enable viewers to appreciate the jokes. Comic failure is likely to result if too much thought is required to understand the joke (Palmer 1994). Thus comedy characters often draw on wider socio-cultural beliefs and assumptions about specific people and individuals. Stereotypes, as a representational strategy, are often used in television comedy to ensure immediate recognition of groups and individuals (Medhurst and Tuck 1982/1996). The characters in one of the most memorable comedy sketches from the 1960s, the "Class" sketch in The Frost Report (BBC 1966-1967), which satirises the complexities of the British class system, are funny not just because of the way they 
interact, but also because they each individually relate to wider dominant social assumptions and understandings of the upper classes (Bowler-hatted John Cleese), the middle classes (trilby-wearing Ronnie Barker), and the working classes (flatcapped Ronnie Corbett) of post-war 1960s Britain. Television comedy can be "read as an indicator of the ways in which the audience it's produced for feels about individuals and groups", or at least, "the kind of audience the broadcaster wishes it to be" (Mills 2005, 101-5). Changing comedic representations reflect social and attitudinal developments across time. This was clearly illustrated in the anti-racist and anti-sexist shifts in social attitudes that led to the rise of Alternative Comedy in the late 1970s/early 1980s (Pickering and Littlewood 1998; Wilmut and Rosengard 1989). It is in this sense that Medhurst (2007) describes comedy as a "cultural thermometer". It is to the "cultural temperature" of social class in contemporary Britain that we now turn.

\section{The emergence of the chav}

The figure of the "chav" and comedic portrayals of chavs are clearly caught up in a number of changing social and political conditions. Despite political and theoretical announcements of the "death of class" and claims that we're living in "classless society" (Clark and Lipset 1991; Holton and Turner 1989; Pakulski and Waters 1996), there are clear indications that British working class inequality and poverty has increased in recent years. ${ }^{\text {iv }}$ Dorling et al. (2007) found that the gap between the richest and poorest in society is the widest it has been for 40 years, and Bladen, Gregg and Machin (2005) have identified how social mobility is declining in Britain.

Further, it has been widely argued, for example by Crompton (1998), Scott (2000), Mount (2004), Lawler (2005), Skeggs (2005), and Hayward and Yar (2006), 
that class continues to be a significant means of analysing forms of inequality. For these authors the complexities of class are not simply a matter of, or restricted to, economic categories or occupation. In addition to economic inequalities, class inequalities circulate symbolically and culturally, for example, through "the means by which people become judged as morally worthwhile, or as having the right kind of knowledge, or 'taste"' (Lawler 2005, 797). Class inequalities and class identities are fluid and dynamic, continually being socially negotiated, renegotiated, and reconfigured through both macro (capital) and micro (symbols and representations) processes (Skeggs 2004; see also Lawler 2005). The symbolic and cultural class signifiers have become increasingly important so that:

"working-class people are not primarily marked as lacking and disgusting through their poverty, but through their assumed lack of knowledge and taste. To be sure, they may be implicitly vilified through a suggestion that they are not spending their money properly - as in critiques that they are now the prey of a vacuous consumer culture - but this implied lack of thrift is in itself assumed to come from a lack of knowledge and taste which would, presumably, enable them to 'see through' consumerism” (Lawler 2005, 800; emphasis in original).

Thus class inequalities are determined by a set of pathological consumption practices (Hayward and Yar 2006, 9), which serve to personalise class identities and class inequalities. The importance of economic capital has been replaced, or at least, supplemented, by cultural capital (Bourdieu 1984). As a result of the increasing importance of these symbolic and cultural class markers, over the last 3-5 years a new social class vocabulary has emerged in Britain (Tyler 2008). ${ }^{\vee}$ The term "chav" has become prevalent in popular discourses to describe socially marginalized groups. "Chav" is now used as a term of disgust and contempt for white working 
class people in British society (Lawler 2005; Tyler 2008). The Oxford English Dictionary now includes an entry for chav, describing him/her as - "a young person of a type characterized by brash and loutish behaviour and the wearing of designerstyle clothes (esp. sportswear); usually with connotations of a low social status".

Chavs have become targets of abuse and have been vilified in news discourses (e.g. The Sun), online discourses (e.g. www.chavscum.co.uk) and populist discourses (e.g. on the reality TV show Big Brother, Channel 4 2000present) (see Tyler 2008). Acronyms, such as "Council Housed and Violent", or "Council Housed and Vile", and slang vocabulary surrounding the "chav" identity, such as, chavellers cheques (benefit payments), are symptomatic of the negativity and hostility underpinning the social contempt of white working class men and women, as are books such as Bok's (2006) The Little Book of Chav Jokes. Further, YouTube videos such as " 5 Ways to Kill a Chav" vi, "Kill a Chav" stickers"vii , the antichav website "Kill the Chav Scum"viii, and some of the definitions of chavs posted on the online slang dictionary, urbandictionary, openly display class-based disgust and contempt towards chavs (see Tyler 2008; Hayward and Yar 2006). For example, one contributor, Shiney McShine, posted the following definition of chavs:

modern name: chav

Ancient name: burberritous wankerous

Poor thieving hobo got nothing better to do that listen to shite music and waste their time talking to other 'chavs'. They like to steal things, phones and wallets particularly, they wear crappy sports brands and tuck their trousers into their socks like a bunch of $f^{\star}$ cking idiots. They are a general waste of 
space and oxygen and I think they should all be boiled in acid, sealed in concrete and dumped in the sea. (Urbandictionary, 28 November 2003)

Unlike earlier class discourses of the late 1980s and early 1990s which focussed on the sphere of production and economic position, contemporary chav discourses focus "not on the inability to consume, but on the excessive participation in forms of market-oriented consumption which are deemed aesthetically impoverished" and the "problem" with chavs is that "they consume in ways deemed 'vulgar' and hence lacking in 'distinction' by superordinate classes” (Hayward and Yar 2006, 14; emphasis in original). Thus in the sphere of consumption chavs wear the "wrong" type of clothing (Burberry caps and Kappa tracksuits), wear too much jewellery (too many sovereign gold rings, thick gold necklaces, ankle-bracelets, and large hoop earrings), wear too much gaudy cheap make-up (or wear too much tangoorange fake tan), binge-drink on cheap lager, and listen to the wrong kinds of music (rap music, "cheesy dance"). The term chav has become synonymous with "ignorance, poverty and violence" (Walker 2008, 1).

Recently The Fabian Society called for a ban on the word chav due to its denouncement of a "voiceless group". It noted that although the middle classes "have always used language to distinguish themselves from those a few rungs below them on the ladder ... this is something new. This is middle class hatred of the white working class, pure and simple" (2008). It identified the portrayals of chavs on national television as contributing to this class hatred, which Burchill has referred to as a form of "social racism" $(2005 ; 2008)$. Populist televisual representations of chavs include (the late) Jade Goody (e.g. on Big Brother), actress and presenter Daniella Westbrook ${ }^{\mathrm{ix}}$, and "comedy chavs" such as teenage schoolgirl chav Lauren Cooper in the sketch show The Catherine Tate Show (BBC 2004-2007), the 
Gallagher family in the dramedy Shameless (Channel 4 2004-present), and the focus of this paper, Little Britain's teenage single mother chav, Vicky Pollard.

\section{Situating Little Britain}

Little Britain is a satirical character-based sketch show written and performed by white middle-class comedy actors, Matt Lucas and David Walliams. Little Britain began as a BBC Radio 4 comedy series in 2001 and transferred to BBC television in 2003, where it ran for three series until 2005. Two Christmas specials, Little Britain Abroad, were broadcast in 2006. ${ }^{\times}$Additionally, Little Britain Comic Relief Sketches Little, Little Britain and Comic Relief: The Big One (both of which included familiar Little Britain sketches with celebrities) were aired in 2005 and 2007, and a sell-out live stage show - Little Britain Live - toured the UK and Australia in 2005-07. An American version, Little Britain USA, was broadcast in late 2008 in America on the HBO channel and in Britain on the BBC. Described by the BBC Guide to Comedy as "an off-kilter look at modern life", Little Britain satirises an array of British, Welsh and Scottish fictitious characters from Marjorie Dawes, leader of weigh loss support group, Fat Fighters, to Daffyd the "only gay in the village", through to eccentric Scottish hotelier, Ray McCooney. Each sketch combines a range of recurring comedic techniques including caricature, drag and repeatable catchphrases. Individual sketches are linked by a voice over (by actor Tom Baker) who announces senseless snippets of "factual" information about Britain. For example, the opening of series 3, episode 1 ran: "Britain, Britain, Britain, a bloody lovely place to live. Discovered in 1972, lost in 1974, then found again a few years later hiding under Belgium. But what makes Britain so fandabidozi? Why, it's the great British public. Aah, push it, push it, ah, push it, push it real good". 
Little Britain has become one of the most talked about programmes on contemporary television. The first episode of the third series had viewing figures of 9.5 million (which accounted for almost $40 \%$ of the television audience) (Bennett, 2005). It has acquired both national and international appeal, has received a number of industry awards, and Matt Lucas and David Walliams were named the most powerful people in television comedy by a Radio Times poll in 2005 (BBC News 2005; The British Sitcom Guide 2008). ${ }^{\text {xi }}$ This success, coupled with it range of merchandising (e.g. CDs, DVDs, videogames, books, dolls, key rings, greeting cards, calendars, t-shirts, jigsaws and mugs) has led to Little Britain becoming one of the most publicly recognised brand images of the twenty-first century.

Despite its popularity Little Britain has continued to court controversy in populist debates. It has been criticised for pushing the boundaries of taste too far, for engaging in the "humour of humiliation" and for being grotesquely un-PC due to mocking minority groups such as the disabled, elderly, and homosexual (see Leapman 2005; Cavendish 2005). For example, Johann Hari in The Independent Online argued that Little Britain "has been a vehicle for two rich kids to make themselves into multimillionaires by mocking the weakest people in Britain. Their targets are almost invariably the easiest, cheapest groups to mock: the disabled, poor, elderly, gay or fat. In one fell swoop, they have demolished protections against mocking the weak that took decades to build up" (2005). Further, The Daily Mail reported:

"The creator of the sitcom Father Ted [Graham Linehan] has criticised comedies such as Little Britain, saying they are crude, cynical and intent on 'trying to humiliate people' ... In a thinly veiled attack on Little Britain ... he added, 'Every second programme seems to be trying to humiliate people and the jokes are becoming very crude."' (2006). 
Little Britain's depiction of the working class, through chav Vicky Pollard, has also heavily criticised. A YouGov survey found that although $70 \%$ of the television industry representatives thought that Vicky Pollard typically reflected today's youth, $40 \%$ of television viewers found Vicky's portrayal offensive (see Martin 2006; Blacker 2006). Tyler (2008) argues that the representation of Vicky Pollard has heightened class antagonisms due to contributing to the widespread class disgust and to "chav hate". As Johann Hari maintains:

"A few years ago, the 1990s backlash against single parents living on crumbling estates - like my sister - was slowly receding. Then Vicky was born. Matt Lucas and David Walliams used the clothes worn by poor people (Kappa, Burberry) and even the names they give their children (Destiny, Shannon, Bethany) as cheap punchlines. They unwittingly incited their armies of child fans to hunt down the Vickys in their playground" (The Independent Online 2005).

It is to Vicky Pollard that we can now turn our attention.

\section{Comedy chav: The case of Vicky Pollard}

Vicky Pollard is a fictional character played by Matt Lucas. Vicky Pollard appears in every series of Little Britain, and is included in the opening sketches of both series 1 and 2. She also appears in 5 out of the 6 episodes of Little Britain USA. She is a single-mother teenage delinquent from the West Country. Through Vicky Pollard we can see a combination of two popular discursive epithets in the class lexicon of difference - the single mother, and the unemployed teenage delinquent (Nunn and Biressi 2008). Hayward and Yar (2006) identify the chav 
single mother as the "softest" stereotypical target of the chav phenomenon. Lucas (2005) argues that Vicky represents the most inarticulate person in Britain who is always engaged in wrong-doing and is frequently put on the spot to explain and account for her actions. Vicky talks at such a fast pace that much of what she says in completely incomprehensible, and her catchphrases include "no but yeah but no but yeah but no", "shut up!", "don't go giving me evils", which she says in her thick Bristolian accent. Vicky's accent serves to position her low on the social hierarchy. As Medhurst explains, different accents are used symbolically to convey social status - "comic characters in many of Shakespeare's plays speak in prose, often use regional dialect and come from the 'lower' social classes, whereas tragic characters speak in poetry, use dominant forms of language and come from 'higher' social echelons" $(2007,16)$. In their historical analysis of predominant representations of the working classes in popular culture Dodd and Dodd (1992) highlight how a symptom of 'middle class anxiety' of working class women in the nineteenth century was a fixation with working class mouths in terms of appetite and their modes and types of speech patterns. The Vicky Pollard characterisation maintains such working class frames and typologies evident in popular culture.

In Little Britain the Vicky Pollard sketches are set in fictional Darkley Noone and in the sketches we see Vicky in institutional settings (schools, court rooms, police stations) or in public settings (swimming pools, on public transport, in supermarkets, corner shops, in pubs). In Little Britain USA we follow Vicky as she joins Wilderness Lodge Boot Camp, a juvenile detention centre in Utah, where she is sent after being thrown out of Disney World for fighting and arson. Whatever the context, we see Vicky interacting with figures who have some sort of authority over her (teachers, barristers, police officers, lifeguards, bus conductors, security guards, shop keepers, publicans, and boot-camp wardens). Much of the comedy is derived from Vicky Pollard's humorous responses to legitimate questions from such authority 
figures. For example, in the Social Worker sketch (series 1, episode 7) when her social worker asks Vicky where her baby is Vicky replies "Swapped it for a Westlife CD". The social worker then asks "How could you do such a thing?", and Vicky replies, "I know, they're rubbish".

Vicky Pollard's low social and cultural status is announced through various cultural signifiers. Epitomising Bakhtin's (1984) grotesque body, Vicky's signature appearance includes her bright pink Kappa shell-suit which is zipped tightly over her portly stomach, her large hooped gold earrings and numerous gold chains, and her long strawberry-blonde hair tightly scrapped up in a scrunchie (colloquially known as a "Croydon facelift"). In episode 3 of Little Britain USA Vicky maintains such appearance at the boot-camp despite all of the other inmates donning a boot-camp uniform. Vicky's appearance epitomises the chav identity that is criticised and mocked on chav-hate websites, popular television, and in press discourses. Yet the grotesque body is ambiguous. In addition to ridiculing bodies, or section of bodies, that are excessive, the grotesque body may simultaneously offer an assault on propriety, refinement, and taste, or bodies of discipline. This lends a significantly different way of understanding and interpreting Vicky's body and audiences' responses to it. This ambiguity will be taken up again later in the discussion when examining Vicky as a contemporary "unruly woman".

Vicky is sexually active - excessively so. She has twelve children fathered by numerous men, constantly talks about her and her friends having (real or imagined) sex - being "fingered", going to "third base", being "felt-up", making "fanny farts", people seeing her or her friends "wookey hole", "forest of dean", "Muller Fruit Corner", "Strawberry Mivvi" - and refers to herself and her peers as "slags", "slagbags", and "bitches". In the Roasting sketch (series 3, episode 3) Vicky tries to convince PR guru Cliff Maxford that having met a group of footballers she "ended up 
doin' sex with all of 'em”. Unconvinced by her first story Vicky goes on to tell Cliff Maxford that she "done a gang band with G4". Vicky's interest in sex may be read as part of her chav-loutishness and therefore strengthens stereotypes that chavs are preoccupied by sex and sexual activity because they lack the cultural capital to enjoy other activities or to have other interests. The representations of Vicky's chav sexuality reflect depictions that are central to representations of working class more widely. Working class sexualities and bodies are typified as excessive, vulgar (Skeggs 1997, 1994), animalistic (Weeks 1981), and associated with undisciplined physicality, such as prostitution (Dodd and Dodd 1992). Yet, as will be discussed later in the discussion, such excessive sexuality, like the grotesque body, is ambiguous and instead of symbolising "chav-loutishness", it may articulate an active rejection of middle class modesty and disciplined behaviour.

There is ample evidence to suggest that Vicky Pollard's character reinforces the class-based contempt of chavs evident elsewhere in popular culture. Numerous Vicky Pollard sketches may be interpreted as ridiculing the perceived stupidity and lack of knowledge of chavs. To take one example, in the Classroom 2 sketch (series 1, episode 1) we see Mr Collier, Vicky's teacher, talking to her about her Lord Kitchener essay:

Mr Collier: Now about this essay.

Vicky: I done it!

Mr Collier: Yep, I have, er, one or two problems with it. "What was Lord Kitchener's role in World War One?" - "No but yeah. In World War One or summink there was this block right called Kitchen or summink or nuffin' who 
done this fing but he ain't not even not done it so shut up. Anyway Kathy reckons she saw Candice getting off with Tony ..." Tozer?

Vicky: Tozer, yeah.

Mr Collier: “... in Foot Locker but anyway don't listen to her because she's got one tit bigger than the other". Vicky, this simply won't do.

Vicky: Why? Is there a problem with spellin'?

Vicky appears to be unable to comprehend why Mr Collier considers her efforts unacceptable - for Vicky the content and grammar is acceptable (which is reinforced by Vicky's head nodding in agreement as Mr Collier reads out her essay). In the first episode of series 2 in the Supermarket sketch we see Vicky attempting to steal pic-n-mix sweets by putting them down her tracksuit trousers (although most of the sweets are simply falling through the tracksuit legs onto the floor). Noticing a security guard watching her Vicky asks: "What are you looking at, pervert?" to which the security guard replies, "I told you before, you've got to put the pic-n-mix in a bag". Vicky replies: "God you're so racist." as she puts sweets into a pic-n-mix bag. She then continues "Alright now?!" as she puts the entire bag down her tracksuit. In his analysis of television comedy representations of social class Butsch argues that the few portrayals of working class individuals that exist in television comedy convey them as "dumb, immature, irresponsible, or lacking in common sense" $(2003,576)$. Vicky Pollard's demeanour and interaction with authority figures reflect such characterisations. Portraying chavs in this manner serves to legitimise their social and cultural position - such representations may imply that chavs simply do not posses the skills and knowledge to be anything other than in their low cultural place. Such comedic class representations are evident in other television comedies, such 
as Steptoe and Son (BBC 1962-1965, 1970-1974) and Only Fools and Horses (BBC 1981-2003). However, the social and political resonance of the Vicky Pollard characterisation is amplified as it taps into the widespread contemporary stream of abuse for white working class groups and individuals seen elsewhere in British popular culture.

In the Supermarket sketch, and other sketches, such as Police Station (series 2, episode 4), Blazin' Squad (series 2, episode 5), Lottery (series 3, episode 6) we witness a manifestation of "the tipster, the travelling salesman, the wheeler-anddealer" theme evident in comedic class discourses identified by Wagg (1998), which, to date, has largely been the preserve of male characters (King 2002). Vicky tries to trick police officers into believing she witnessed a robbery in order to receive a $£ 10,000$ reward, attempts to convince a bouncer that she is friends with members of the band Blazin' Squad and should be allowed backstage to meet the group despite not having the required backstage pass, and endeavours to convince a newsagent that she has won the lottery jackpot with her homemade lottery ticket. Such comedic chav representations reinforce Harding's (2006) observation that all groups and individuals who are "othered", are constructed as threatening social and moral order.

The perfomative dynamics of a male middle-class actor playing a female delinquent unemployed single mother reinforces Tyler's view that "the vilification of the chav can be interpreted as a symptom of a middle-class desire to re-demarcate class boundaries with in the context of contemporary consumer culture" $(2008,22)$. As a popular British comedic technique drag offers the comic performer opportunity to play with power and status differentials. King observes that a woman dressing as a man is less comical or absurd due to increased access to "power and resources" that results from the female-to-male drag. Whereas for a "man to dress as a woman is to trade downwards, in patriarchal terms, a seemingly less 'rational' and therefore 
potentially more comic manoeuvre" $(2002,141)$. Thus men may cross-dress because they wish to be taken humorously. Cross-dressing is not simply confined to issues related to gendered identity. Senelick (2000) argues that aspects and questions of class, power, spectacle and the visible are brought to the fore in crossdressing. While the dynamics of males masquerading as females apply to Matt Lucas playing Vicky Pollard, the absurdity is further extended due to the social class masquerade. Here we witness a middle class male masquerading as a working class female, where the "trading downwards" in gender terms is coupled with downward trading in class terms - a middle class person masquerading as working class again is less "rational" (and more comical) given the lack of social, economic and political opportunities and privileges afforded to the working classes, compared to the middle classes.

Vicky Pollard has had extraordinary socio-political influence, which highlights the significance of fictional comedic television characters in our everyday sense making. The term "Vicky Pollard" has become synonymous for "chav", and for some, such as Daily Star journalist Diamond, Vicky Pollard represents a "genuine social type" (Tyler 2008, 28). Vicky Pollard, and her negative comedic connotations, have been used to deny individuals and groups opportunities, and has been used as a term of abuse. There have been press reports of Primary School Heads writing to parents complaining that children were using language not welcome within the school gates due to them repeatedly using Vicky Pollard's "No but yeah but not but yeah" catchphrase (Sapsted 2005), a contestant on the reality television show The $X$-Factor (ITV 2004-present) was prevented from proceeding to the next round of the contest because she resembled Vicky Pollard, and in political debates measures have been proposed with the specific aim of preventing the creation of "a generation of Vicky Pollards" (see Tyler 2008). 


\section{No but yeah but no ... complex comedy chavs}

For Tyler Vicky Pollard has "become entrenched and condemned as a negative figure" $(2008,28)$. The above analysis lends itself to this interpretation of Vicky Pollard, and suggests that the Vicky Pollard character is firmly situated within the widespread vilification of chavs. However, such analysis offers one political reading of the Vicky Pollard character, and fails to acknowledge the complexities inherent in comedic discourses. Features that would be removed from serious discourse - ambiguity, contradictions and interpretive diversity - are fundamental features in comedy (Mulkay 1988; Fine 1983; Koestler 1964). A number of highprofile "comedy controversies" have occurred due to ambiguity in the meaning, motive, and intent of comedic discourse. For example, diverse interpretations were made of Alf Garnett, the central character in the 1960s television situation comedy Till Death Us Do Part (BBC 1965-1975). xiii Although comedy writer Johnny Speight argued that Alf Garnett ridiculed the stupidity and ignorance of bigots, some viewers interpreted the programme, and the character Alf Garnett, as celebrating racism (Husband 1988). Pickering and Lockyer refer to this as the "Alf Garnett Syndrome", where "what is being satirised becomes a source of celebration among at least a section of the audience" (2005, 16-17). Medhurst usefully identifies the ideological consequences of such interpretive diversity - whist comedy may be attacked as "divisive, exclusionary, in league with prejudice, a weapon of the powerful, an activity dedicated not only to supporting inequalities but also to cloaking them in an aura of inevitability", it can also be "unifying, inclusive, a weapon against prejudice, a voice for the marginalised, a way of exposing discrimination through highlighting its absurdities" $(2007,19)$. King refers to this as a "double-edged potential" $(2002,145)$, which permits comedy to "both question and reconfirm prevailing definitions ... giving it a potent but also ambiguous ideological potential" $(2002,129)$. The Vicky Pollard characterisation and performance is ambivalent, contradictory and oppositional. Her 
characterisation and diegesis offer alternative, more positive, interpretive possibilities to those discussed above. There are moments in the Little Britain series when a more sympathetic tone is shown towards Vicky Pollard and progressive moments when Vicky Pollard is used to mock the idiosyncrasies of middle class identities and lifestyles. It is worth considering these in more detail.

Vicky Pollard may be interpreted as offering a contemporary construction of the "unruly woman" (Rowe 1995) whose body resists and challenges middle class control and decorum. Vicky Pollard is reminiscent of other large working class female comic characters, such as Roseanne (ABC 1999-1997) ${ }^{\text {xiv }}$ (see Rowe 1995; Chambers 2005). Examining the progressive qualities of Roseanne, Rowe explains that it is precisely her body size and shape, and the "looseness or lack of personal restraint her fatness implies, that most powerfully define her and convey her opposition to middle-class and feminine standards of decorum and beauty" (1995, 60; emphasis in original). This equally applies to Vicky Pollard. Vicky's rotund figure, her garish make up, spotty face, bright pink tracksuit and long hair tightly scrapped back in a scrunchie, transgresses many of the boundaries regarding female appearance that contemporary western makeover programmes, such as What Not to Wear, (BBC 2001-2007) and 10 Years Younger (Channel 4 2004-present) attempt to fix. Makeover programmes, through mockery and ridicule, which Gill (2008) calls the "new cruelty", humiliate working class bodies for lacking taste, style and refinement. But through the duration of these makeover programmes working class bodies are replaced and re-sculptured so they look more middle class - reflecting bodies that are controlled, policed and disciplined (see Wood and Skeggs 2004), and become distanced from their working class bodies of excess. Vicky Pollard does not ascribe, nor attempts to ascribe, to the desire or need to re-sculpture her body so it reflects decorum and discipline. Nor does her small untidy and cluttered bed-sit subscribe to the clean and tidy living spaces endorsed on Western lifestyle programmes such as 
How Clean is Your House? (Channel 2003-present) or The Life Laundry (BBC 20022004). In this sense Vicky Pollard can be viewed as a character of rebellion, resistance, and defiance to social control and hegemonic ideologies that are repeated and reinforced elsewhere in British contemporary popular culture.

Reinforcing one of Medhurst's (2007) five discursive themes underpinning class comedy, the Vicky Pollard character can be interpreted as, on occasion, ridiculing the behaviours of the middle classes. In the Classroom 2 sketch (series 1 , episode 1) noted above Vicky Pollard's difficulty in understanding why Mr Collier may regard her Lord Kitchener essay as problematic, could, for some viewers, be interpreted as "faux naivety". Such "faux naivety" may serve to ridicule Mr Collier's teacherly seriousness and the manner in which secondary school teachers speak to, and interact with, their pupils. Further, in the Babysitter 1 and 2 sketches (series 3 , episode 5) we witness a middle class couple, Jennifer and Richard, permit Vicky to baby sit their son, Archie, as they enjoy an evening out. On their return the couple encounter the devastation caused to their tasteful and ordered town house by the party Vicky has held in their absence (curtains, furniture and pictures have been trashed, graffiti has been sprayed on the lounge wall, a fire is ablaze on the sofa, track-suited teenagers are swigging alcohol, dancing to loud music and trying "to get off" with each other). The following exchange ensues:

Jennifer: Vicky!

Vicky: What are you doing here? You ain't invited.

Richard: Where's Archie? Is he alright?

Vicky: Yeah. We sent him down the offy to get some more fags. 
Jennifer: What?!

Vicky: Don't go giving me evils - we given him fake ID. Anyway I am actually quite busy at the moment tryin' to get off with this bloke actually if you don't mind actually!

Richard: Get out! Get out of my house!

Vicky: Don't worry. We're going. This party is like well sad anyway. And I found your pornos, you dirty bastard.

The ending to this sketch can be interpreted as an attempt to reveal and ridicule the pretentious nature of middle class domestic arrangements, or exposing the "reality" behind happy harmonious middle class families. Although earlier in the sketch the couple call each other "darling", Richard calls his wife "Beautiful", and on their return to their home (before they notice the party Vicky has thrown), Jennifer says to Richard “Hey - no yawning from you. The night isn't over yet!", Vicky's comment that she found Richard's "pornos", and calling him a "dirty bastard" uncovers Richard's secret, thus revealing the "true" nature of couple's relationship. Juxtaposing specious Richard with self-knowing Vicky who calls herself "like well a slag" (Call Centre sketch, series 3, episode 2) highlights the unpretentious character of chavs, and the pretentious nature of middle class identities and culture. As with other comedic working class characters Vicky never thinks of herself as being more than she actually is. As Wagg notes in his analysis of Del and Rodney Trotter in Only Fools and Horses, "the trotters are part of a coterie of duckers and divers and bit-of-this, bit-of-that merchants who sometimes have money and sometimes don't but, like Sharon and Tracey [in Birds of a Feather, BBC 1989-1998], never think of 
being other than they are" $(1998,28)^{\mathrm{xv}}$. In this context unpretentiousness may be interpreted as a redeeming quality making up for, what some audience members may regard as, Vicky's taste and knowledge "deficiencies". Further, Skeggs (2004, 116) argues that this anti-pretension critique is "about blocking their [those with more moral authority] ability to apply moral judgement." Thus the Babysitter sketches may be read as offering chavs temporary respite from middle and upper class moral assessments.

This sketch may also serve to expose middle class hypocrisy, or what Burchill and Newkey-Burden (2008) call "modern hypocrisy". Burchill argues that "every aspect of chav-hatred is riddled with hypocrisy" $(2008,133)$. A dimension of this hypocrisy is illustrated by the middle classes, who on the one hand denounce chav culture for its binge-drinking unruly behaviour, but who on the other will happily economically exploit chavs and will invite them into their middle class homes to complete tasks that are poorly paid, and are based on irregular and unsociable hours (in this case, babysitting).

There are moments across the series when the narrative development proffers a more sympathetic stance towards Vicky and her life, where we, as the audience are encouraged to feel remorseful towards Vicky. In the At the Doctors sketch (Series 1, episode 6) where after examination Vicky's doctor confirms that she is eight months pregnant the doctor says :OK, Vicky. Well, um, I would strongly advise you, if you haven't already, for the sake of your baby, to give up smoking and drinking”. Vicky replies “On my God I so can't believe you just said that! I smoked like once for two years when I was like nine and I only drink to numb the pain of my worthless life so you're well out of order". Further, in The Lottery sketch (series 3, episode 6) following accusation from the shopkeeper that Vicky has made her own (winning) lottery ticket Vicky replies: “... yeah but I did bit I didn’t but I did but I didn’t 
because I couldn't because I was actually busy doing two million hours community service and anyway I couldn't have made it myself even if I had actually wanted to actually because I can't read or write because l'm like totally lexdykslyk." Although Finding (2008) suggests that some audience members watching the At the Doctors sketch may agree that her life is in actual fact worthless, such self-reflexivity and selfawareness demonstrated by Vicky Pollard is a stark contrast to the negative hypocritical behaviour demonstrated by many members of the middle classes (Burchill 2008).

\section{Discussion}

Little Britain has maintained British television comedy's "obsession" (Medhurst 2007, 145) with class through its "comedy chav", Vicky Pollard. Class politics continue to be symbolically exercised in television comedy in complex ways. Little Britain's relationship to contemporary shifting markers and understandings of class cultures and class identities is however both confirmatory and contradictory. Comic characters have the ability to ridicule, as well as to be ridiculed, or to mock as well as to be mocked. Comic characters, such as Vicky Pollard, operate as significant vehicles for exposing the contradictory feelings that resonate around contemporary social class hierarchies. Although these contradictions may, to some extent, have underpinned early television comedic constructions of social class, the Vicky Pollard character has brought them to the fore in contemporary programming.

Vicky Pollard's excessive sexuality, body, and language, and lack of selfgovernance symbolically attaches negative value to chav identities and cultures, and constructs chavs as a threat to contemporary moral and social order. Thus Vicky Pollard's construction can be interpreted as contributing to the demonization of chavs evident elsewhere in popular culture. However, the above analysis cautions against 
one-dimensional interpretations of Vicky Pollard. Her ambivalence facilitates an interpretation that places Vicky Pollard as a contemporary "unruly woman" who rebels against, and is resistant to, cultural demands to restrain, restrict and define her working class body and behaviour so it reflects middle class discipline and governance. Further, the anti-pretension critique evident in some sketches, such as the Babysitter sketch, serves to highlight negative aspects of middle class identities and cultures and exposes the hypocrisy that underpins middle class resentment of chavs. Although the anti-pretension critique appears momentarily, together with more positive progressive interpretations of Vicky Pollard, it does extend and openup the political comedic readings made possible. As with other controversial comedic characters (such as Alf Garnett) there is no one single unitary joke underpinning the Vicky Pollard sketches. The interpretive diversity underpinning this chav comedy text is possible precisely because of wider socio-political concerns and anxieties surrounding class distinctions and its particular historical moment.

Whist this paradoxical nature of comedy is interesting and significant when considering the progressive political possibilities of contemporary class comedy and opportunities for challenging dominant class ideologies, drawing attention to the contradictory nature of the comic mode can be used to sustain hierarchical class positions when class characterisations are criticised. For example, in response to the comment "We look back on Jim Davidson blacking up as a head-scratching, imbecile black man with horror. But why is a public schoolboy dressing up as a head-scratching, imbecile single mother any better?" David Walliams retorts "These characters are fun. You want to spend time with them. You don't despise them. You're laughing with them, not at them" (quoted in Hari 2005). In this way the comic mode simultaneously permits the legitimation and exoneration of class stereotypes. 
When audiences exhibit what Lewis (1987) refers to as an "antijoke" response, or what Billig (2005) calls "unlaughter", and criticise comedians or specific programmes for unfairly targettting specific classed groups or individuals, or causing offence to particular classes, they can retort, "it's just a joke" or that it was just fooling around. The "it's just a joke" response is "one of the most widely employed dodges in the history of man" (Goffman 1974, 331), and can be used as a rhetorical strategy to curtain serious critical debate about the political implications of, and ethical limits to comedy (see Lockyer and Pickering 2005; 2008). Further, the comedian can claim that comedy critic has "failed to get the joke", or has misinterpreted the butt of the joke. This rhetorical strategy becomes particularly significant politically if it is used as a defence for the repeated and routine mocking of specific class groups.

Little Britain, and the Vicky Pollard character in particular, has made "class differences and antagonisms explicitly visible" (Tyler 2008, 20) in contemporary British popular culture. Although some audiences may interpret and make sense of Vicky Pollard as a figure to hate, and others could interpret her character as more progressive and positive (or something in between these two interpretative possibilities), it is clear from the above discussion that television comedy has been, and continues to be, a significant discourse through which concerns, anxieties, and questions about class and class identities in Britain are discursively constructed and contested. 


\section{Acknowledgments}

Grateful thanks to Mike Pickering and Milly Williamson for useful comments on an earlier draft of the paper, and to the two anonymous reviewers for their thoughtful suggestions.

\section{Author Biography}

Sharon Lockyer is a Lecturer in Sociology and Communications in the School of Social Sciences at Brunel University, UK. Her research interests are in the sociology of mediated culture and critical humour studies. She is co-editor (with Michael Pickering) of Beyond a Joke: The Limits of Humour (Palgrave, 2005) and has published in a variety of academic journals including Discourse and Society; Journalism Studies; International Journal of Social Research Methodology: Theory and Practice; Ethical Space; Sociology Compass; and Popular Communication: The International Journal of Media and Culture. She was the recipient of the International Society for Humor Studies (ISHS) Emerging Scholar Award in 2004. 


\section{References}

Andrews, Maggie. 1998. Butterflies and caustic aides: Housewives, comedy and the Feminist Movement. In Because I tell a joke or two: Comedy, politics and social difference, ed. Stephen Wagg, 50-64. Routledge: London.

Bakhtin, Mikhail M. 1984. Rabelais and his world. Trans. H. Iswolsky. Bloomington: Indiana University Press.

Battles, K., and Hilton-Morrow, W. 2002. Gay characters in conventional spaces: Will and Grace and the situation comedy genre. Critical Studies in Media Communication 19, no. 1: 87-105.

Bennett, Steve. 2005. Little Britain, large audience. BBC Comedy Blog, http://www.bbc.co.uk/comedy/news/2005/11/21/27421.shtml

Billig, Michael. (2005) Laughter and ridicule: Towards a social critique of humour. London: Sage.

Blacker, Terence. 2006. British humour had always been in a class of its own, The Independent Online, August 29, http://www.independent.co.uk/opinion/commentators/terence-blacker/terenceblacker-british-humour-has-always-been-in-a-class-of-its-own-413741.html

Blanden, J., Gregg, P., and Machin, S. 2005. Social mobility in Britain: Low and falling. CentrePiece (Spring): 18-20.

Bok, Lee. 2006. The little book of chav jokes. Bath: Crombie Jardine Publishers. 
Bourdieu, Pierre. 1984. Distinction: A social critique of the judgement of taste. London: Routledge and Kegan Paul.

Bowes, Mick. 1990. Only when I laugh. In Understanding television, ed. Andrew Goodwin and Garry Whannel, 128-40. London: Routledge.

BBC Guide to Comedy. 2007. Little Britain, http://www.bbc.co.uk/comedy/guide/articles///lttlebritain_1299003526.shtml

BBC News. 2005. Little Britain two top comic list, BBC News Online, January 10, http://news.bbc.co.uk/1/hi/entertainment/tv_and_radio/4161579.stm

Burchill, Julie. 2005. Yeah but, no but, why l'm proud to be a chav. The Times 2, 18 February: 4.

Burchill, Julie. 2008. Chav-haters. In Not in my name: A compendium of modern hypocrisy, Julie Burchill and Chas Newkey-Burden, 132-142. London: Virgin.

Butsch, Richard. 2003. Ralph, Fred, Archie, and Homer: Why television keeps recreating the white male working-class buffoon. In Gender, race and class in media: $A$ text-reader, $2^{\text {nd }}$ ed, Gail Dines and Jean M. Humez, 575-82. Thousand Oaks: Sage.

Butsch, R., and Glennon, L.M. 1983. Social class: Frequency trends in domestic situation comedy, 1946-1978. Journal of broadcasting 27, no. 1: 77-81.

Cavendish, Dominic. 2005. Big laughs at Little Britain: Lucas and Walliam's 
grotesque characters shocked and awed comedy lovers. The Daily Telegraph, December 24: 16.

Chambers, Deborah. 2005. Comedies of sexual morality and female singlehood. In Beyond a joke: The limits of humour, ed. Sharon Lockyer and Michael Pickering, 162-79. Basingstoke: Palgrave.

Channel 4. n.d. Britain's favourite celebrity chav, http://www.channel4.com/entertainment/tv/microsites/G/greatest/chavs/results tml

Clark, T., and Lipset, S.M. 1991. Are social classes dying? International Sociology 6 , no. $4: 397-410$.

Crompton, Rosemary. 1998. Class and stratification: An introduction to current debates. $2^{\text {nd }}$ ed. Cambridge: Polity Press.

Crowther, Bruce, and Mike Pinfold. 1987. Bring me laughter: Four decades of TV comedy. London: Columbus Books.

Devereux, Eoin. 2007. Understanding the media. $2^{\text {nd }}$ ed. London: Sage.

Dodd, Kathryn, and Philip Dodd. 1992. From the east end to EastEnders: Representations of the working class, 1890-1990. In Come on down?: Popular media culture in post-war Britain, ed. Dominic Strinati and Stephen Wagg, 116-32. London: Routledge. 
Dorling, Daniel, Jan Rigby, Ben Wheeler, Dimitris Ballas, Bethan Thomas, Eldin Fahmy, David Gordon, and Ruth Lupton. 2007. Poverty, wealth and place in Britain, 1968 to 2005. Bristol: The Policy Press.

Dugan, Emily. Little Britain Enters Record Books with £3m DVD. The Independent Online. 27 September 2007. http://www.independent.co.uk/news/media/littlebritain-enters-record-books-with-pound3m-dvd-403665.html

Finding, D. 2008. "I can't believe you just said that": Figuring gender and sexuality in Little Britain. Media@LSE Electronic Working Papers. No. 13, http://www.Ise.ac.uk/collections/media@Ise/mediaWorkingPapers/ewpNumbe r13.htm

Fine, Gary Alan 1983. Sociological approaches to the study of humor. In Handbook of humor research: Volume 1 Basic Issues, ed. Paul McGhee and Jeffrey Goldstein, 159-181. New York: Springer-Verlag.

Gill, R. 2008. Empowerment/sexism: Figuring female sexual agency in contemporary advertising. Feminism and Psychology 18, no. 1: 35-60.

Goffman, Erving. (1974) Frame analysis: An essay on the organization of experience. Boston: North eastern University Press.

Gray, Frances. 1994. Women and laughter. Basingstoke: Macmillan.

Gray, Frances. 1998. Suits and sequins: Lesbian comedians in Britain and the US in the 1990s. In Because I tell a joke or two: Comedy, politics and social difference, ed. Stephen. Wagg, 146-64. Routledge: London. 
Harding, R. 2006. Historical representations of aboriginal people in Canadian news media. Discourse \& Society 17, no. 2: 205-35.

Hari, Johann. 2005. Why I hate Little Britain. The Independent Online, November 22, http://comment.independent.co.uk/columnists_a_l/johann_hari/article328516. ece

Hayward, K., and Yar, M. 2006. The "chav" phenomenon: Consumption, Media and the construction of a new underclass. Crime, Media, Culture 2, no. 1: 9-28.

Henry, Matthew. 2004. Looking for Amanda Hugginkiss: Gay life on The Simpsons. In Leaving Springfield: The Simpsons and the possibility of oppositional culture, ed. John Alberti, 225-43. Detroit, Michigan: Wayne State University Press.

Hole, A. 2003. Performing identity: Dawn French and the funny fat female body. Feminist Media Studies 3, no. 3: 316-28.

Holton, Robert J. and Bryan S. Turner. 1989. Max Weber on economy and society. London: Routledge.

Howells, R. 2006. "Is it because I is black?": Race, humour and the polysemiology of Ali G. Historical Journal of Film, Radio and Television 26, no. 2: 155-77.

Husband, Charles. 1988. Racist humour and racist ideology in British television, or I laughed till you cried. In Humour in society: Resistance and control, ed. Chris Powell and George E.C. Paton, 149-78. Hampshire: Macmillan. 
Kirkham, Pat, and Beverley Skeggs. 1998. Absolutely Fabulous: Absolutely feminist?. In The television studies book, ed. Christine Geraghty and David Lusted, 287-98. London: Arnold.

King, Geoff. 2002. Film comedy. London: Wallflower.

Koestler, Arthur. 1964. The act of creation. London: Hutchinson.

Lawler, S. 2005. Introduction: Class, culture and identity, Sociology 39, no. 5: 797806.

Leapman, Michael. 2005. Littler Britain: Once scathingly witty, why has the gloriously un-PC Little Britain suddenly lost its way? The Daily Mail, December 13: 15.

Lewis. Paul. (1987) Joke and anti-joke: Three Jews and a blindfold. The Journal of Popular Culture 21, no. 1: 63-73.

Lockyer, Sharon, and Michael Pickering. (2005) Beyond a joke: The limits of humour. Basingstoke: Palgrave.

Lockyer, Sharon, and Michael Pickering. (2008) You must be joking: The sociological critique of humour and comic media. Sociology Compass 2, no 3: 808-20.

Lucas, Matt. 2005. Radio 5 Live interview. Little Britain: The complete first series. DVD. BBC Worldwide Ltd. 
Malik, Sarita. 2002. Representing black Britain: A history of Black and Asian images on British television. London: Sage.

Martin, Lorna. 2006. Cracker creator blasts "Chav" TV: Studio bosses "ridicule white working classes", The Observer, August 27, http://www.guardian.co.uk/media/2006/aug/27/broadcasting.uknews

Medhurst, Andy. 1998. Laughing matters: Situation comedies. In The colour black: Black images in British television, ed. Therese Daniels and Jane Gerson, 1560. London: BFI.

Medhurst, Andy. 2007. A national joke: Popular comedy and English cultural identities. London: Routledge.

Medhurst, Andy, and Lucy Tuck. 1982/1996. 'Situation comedy and stereotyping'. In Television times: A reader, ed. John Corner and Sylvia Harvey, 111-16. London: Arnold.

Meyer, Moe. 1994. The politics and poetics of camp. London: Routledge.

Mills, Brett. 2005. Television sitcom. London: British Film Institute.

Mount, Ferdinand. 2004. Mind the gap: The new class divide in Britain. London: Short Books.

Mulkay, Michael. 1988. On humour: Its nature and place in modern society. London: Basil Blackwell. 
Nayak, A. 2006. Displaced masculinities: Chavs, youth and class in the postindustrial city, Sociology 40, no. 5: 813-31.

Nunn, A., and Biressi, A. 2008. Reflections on the "undeserving poor", Soundings, http://www.Iwbooks.co.uk/journals/soundings/class_and_culture/nunnbiressi.h $\mathrm{tml}$

Pakulski, Jan, and Malcolm Waters. 1996. The death of class. London: Sage.

Palmer, Jerry. 1994. Taking humour seriously. London: Routledge.

Pickering, M. 1994. Race, gender and broadcast comedy: The case of the BBC's Kentucky Minstrels, European journal of communication 9, no. 3: 311-33.

Pickering, Michael, and Jane Littlewood. 1998. Heard the one about the white middle-class heterosexual father-in-law'? Gender, ethnicity and political correctness in comedy. In Because I tell a joke or two: Comedy, politics and social difference, ed. Stephen Wagg, 291-312. London: Routledge.

Pickering, Michael, and Sharon Lockyer. 2005. Introduction: The ethics and aesthetics of humour and comedy. In Beyond a joke: The limits of humour, ed. Sharon Lockyer and Michael Pickering, 1-24. Basingstoke: Palgrave.

Porter, Laraine. 1998. Tarts, tampons and tyrants: Women and representation in British comedy. In Because I tell a joke or two: Comedy, politics and social difference, ed. Stephen Wagg, 65-93. Routledge: London.

Rowe, Kathleen. 1995. The unruly woman: Gender and the genres of laughter. 
Austin, Texas: University of Texas Press.

Sapsted, David. 2005,. Headmistress calls for Little Britain ban. The Daily Telegraph, December 17: 11 .

Scott, John. 2000. Class and stratification. In Social divisions, ed. Geoff Payne, 2054. Basingstoke: Palgrave.

Senelick, Laurence. 2000. The changing room: Sex, drag and theatre. London: Routledge.

Simpson, Mark. 1998. The straight men of comedy. In Because I tell a joke or two: Comedy, politics and social difference, ed. Stephen Wagg, 137-45. London: Routledge.

Skeggs, Beverley. 1997. Formations of class and gender: Becoming respectable. London: Sage.

Skeggs, Beverley. 2004. Class, self, culture. London: Routledge.

Skeggs, B. 2005. The making of class and gender through visualizing moral subject formation. Sociology 39, no. 5: 965-82.

The British Sitcom Guide. 2008. About “Little Britain”, http://www.sitcom.co.uk/little_britain/about.shtml

The Daily Mail. 2006. Little Britain blasted by Father Ted. January 12: 33. 
The Fabian Society. 2008. Stop using chav: It's deeply offensive, http://fabians.org.uk/publications/extracts/chav-offensive

Tyler, I. 2008. "Chav mum chav scum": Class disgust in contemporary Britain. Feminist Media Studies 8, no. 1: 7-34.

Urbandictionary 2003. Chav. http://www.urbandictionary.com/define.php?page=3\&term=chav

Wagg, Stephen. 1998. 'At ease, corporal': Social class and the situation comedy in British television, from the 1950s to the 1990s. In Because I tell a joke or two: Comedy, politics and social difference, ed. Stephen Wagg, 1-31.London: Routledge.

Walker, J.K. 2008. "Chav": The emergence of a new identity. Interstice: A Journal of Literary and Cultural Studies 1, no. 1: 1-12, http://film.selfip.net/ojs/index.php/interstice

Weeks, Jeffrey. 1981. Sex, politics and society: The regulation of sexuality since 1800. Harlow: Longman.

Wilmut, Roger, and Peter Rosengard. 1989. Didn't you kill my mother-in-Law?: The story of Alternative Comedy in Britain from the Comedy Store to Saturday Live. London: Methuen.

Wood, H., and Skeggs, B. 2004. Notes on ethical scenarios of self on British reality TV. Feminist Media Studies 4, no. 2: 205-8. 
Dynamics of Social Class Contempt in Contemporary British Television Comedy

Zizek, S. 2000. Camp comedy. Sight and sound 10, no. 4: 26-9. 


\section{Notes}

' Club Night was set in a Working Men's club in the North of England and The Royle Family focuses on the life of The Royles, a working class family living in Manchester.

ii Keeping Up Appearances follows the class struggles experienced by Hyacinth Bucket (which she insists is pronounced "Bouquet") as she attempts to appear as a member of a higher social class than she actually is. Hancock's Half Hour starred Tony Hancock who played an exaggerated version of himself, Anthony Aloysius St John Hancock, an impoverished comedian waiting for success whilst struggling to survive. My Family is based around the life and relationships of a middle class family, The Harpers, who live in Chiswick, London, headed by Dentist Ben Harper and artist-gallery worker Susan Harper. Ever Decreasing Circles takes a satirical look at modern suburban life where Martin Bryces' organised and happy life is threatened when a new neighbour, Paul Ryman (who runs a successful hairdressing salon), moves into the cul de sac. The sketch show Harry Enfield and Chums included a diverse array of characters, including The Slobs Wayne and Waynetta - an unhygienic couple living on social security benefits. Absolutely Fabulous focuses on the female middle class lifestyles and excess of Edina Monsoon, a 40-ish year old public relations executive, and her best friend Patsy.

iii The sitcom Only Fools and Horses was set in Peckham in London and followed the trials and tribulations of the Trotter family in their attempt to rise up the social ladder from their market-trader roots. The family included Derek "Del Boy" Trotter, his bother Rodney, their grandfather, and in later episodes, their uncle. To the Manor Born was a sitcom centred on the love-hate relationship between upper-class Audrey fforbes-Hamilton and Richard DeVere, a nouveau rich millionaire. When Audrey's husband dies she moves out of her manor house, which is bought by Richard. Drop the Dead Donkey, a sitcom, was set in the offices of "Globelink News", a television news company, and tracked the battles between "Globelink" staff on one hand and its proprietors' deputy on the other over editorial standards and content. 


\footnotetext{
${ }^{\text {iv }}$ After winning the 1959 election Conservative Prime Minister Harold Macmillan announced that "the class war is over". Almost 30 years later John Major's aim was to turn Britain into a classless society. Further, both Margaret Thatcher and Tony Blair sought to break down class barriers (see Mount 2004).
}

${ }^{\vee}$ Chav was 2004's word of the year (Burchill 2005). The etymology of the term is largely contested (Skeggs 2005). Some believe that the word is based on an old Romany/Gypsy word for child (Devereux 2007), a community that has experienced marginalization and social exclusion (Hayward and Yar 2006), whereas other believe the word derives from a combination of characteristically lower-class names, Sharon and Trevor (Shar/vor) (see Nayak 2006).

${ }^{\text {vi }}$ http://www.youtube.com/watch?v=FqLyVEAGoBo

vii http://www.smellyourmum.com/catalog/product_info.php?products_id=451

viii http://www.freewebs.com/killthechavscum/index.htm

${ }^{i x}$ Daniella Westbrook was voted Britain's Favourite Celebrity Chav in a Channel 4 poll (Channel 4 n.d.)

${ }^{x}$ The first television series of Little Britain was broadcast on BBC's digital channel BBC Three in 2003. The second series was broadcast on BBC Three in October 2004, and repeated on BBC 1 later in the same year. Series three was broadcast on BBC 1 in November 2005.

\footnotetext{
${ }^{x i}$ Awards include the British Comedy Awards 2004 (for Best TV Comedy, People's Choice Award, and Best TV Comedy Actor (David Walliams), the British Comedy Awards 2005 (for Best Comedy Programme and the Ronnie Barker Writers' Award), National TV Awards 2005 (for Most Popular Comedy Programme), BAFTA 2005 (for Best Comedy Programme), and two Rose D'Or Awards.
} 
xii Little Britain appears in the 2008 Guinness World Records as the DVD of the first two series sold 645,457 copies between March 2006 and 2007, making it the best-selling comedy DVD in the world (Dugan 2007).

xiii The British sitcom Till Death Us Do Part focused on the Garnett family from the East End of London, headed by white working-class Alf Garnett.

${ }^{\text {xiv }}$ Roseanne, an American sitcom, starring stand-up comedian Roseanne Barr, focussed on the highs and lows of a working class family living on limited finances.

${ }^{x v}$ The British sitcom Birds of a Feather follows the lives of sisters Sharon and Tracey who live together in Tracy's house in Chigwell, Essex, UK following the imprisonment of their husbands who were convicted of armed robbery. 